\title{
PRINCIPAL'S LEADERSHIP IN REALIZING CHARACTER EDUCATION
}

\author{
Sutino ${ }^{*}$, Sowiyah ${ }^{2}$, Sri Endang ${ }^{3}$, Novita Eka Tristiana ${ }^{4}$ \\ 1,2,3 Universitas Lampung, Lampung, Indonesia \\ 4Universitas Muhammadiyah Pringsewu, Lampung, Indonesia \\ *tinokliwon@gmail.com
}

\begin{tabular}{|c|c|}
\hline Article Info & ABSTRACT \\
\hline $\begin{array}{l}\text { Article history } \\
\text { Received May 26, } 2021 \\
\text { Revised June 5, 2021 } \\
\text { Accepted August 16, } 2021\end{array}$ & \multirow{2}{*}{$\begin{array}{l}\text { Several articles on the review of principals' leadership and } \\
\text { character education, especially in the world context, can be } \\
\text { found. The purpose of this review is to find out the principal's } \\
\text { leadership in realizing character education in a world context. } \\
\text { Based on the literature reviews from various countries globally, } \\
\text { the authors find the scope of the article being reviewed is still } \\
\text { minimal. It is not very easy to get literature that combines the } \\
\text { two variables; therefore, the writer will positively explain the } \\
\text { findings for each variable. The literature review results about } \\
\text { the principal's leadership show that the principal's leadership } \\
\text { in carrying out his role as a leader impacts teacher } \\
\text { performance and student personality. Literature review of } \\
\text { character education shows that the principal has a significant } \\
\text { role in realizing student personality. Thus, the authors are } \\
\text { interested in following up on the principal's leadership in } \\
\text { realizing character education. }\end{array}$} \\
\hline $\begin{array}{l}\text { Keywords: Character } \\
\text { Education; Education; } \\
\text { Principal's Leadership; }\end{array}$ & \\
\hline
\end{tabular}

\section{INTRODUCTION}

Education is expected to direct students to get a better understanding of the sciences that can benefit their lives. Education is the primary means of providing input to students to be able to then live in their neighborhood. (Brooks, Hughes, \& Brooks, 2008). Education functions in encouraging students to be able to live appropriately and be familiar with their environment. Education is expected to prepare students to be able to live their lives well, but not infrequently. It contradicts that expectation. Education apparently can also make students feel unfamiliar with the reality of life contained in their environment. (Wibowo, Madjid, \& Marietta, 2018). Today, there is a pedagogical model based on character education because character education can be realized as an instrument of learning that is close and applicable to life. Students do not have to learn things that are not close to their lives or are not experienced. Character education can bring students to better understand social life by first trying to recognize themselves. (Li, Hallinger, \& Ko, 2016). Child-friendly schools are academic units in every planning, learning activity, and policy guaranteeing children avoid violence through a friendly, safe, and healthy environment (Minister of Women's Empowerment and Child Protection Regulation No. 8 of 2014 concerning Child-Friendly School Policies). The goals of Child-Friendly Schools are: First, to guarantee that every child is protected from violence. Second, the education unit prepares children to grow and develop into responsible individuals. (Nir \& Kranot, 2006). Leadership has increasingly been seen as a "group function: it occurs only when two or more people interact," and thus, leaders "intentionally seek to influence the behavior of other people" rather than command, the latter being dependent on obedience and compliance. Recent research has shown that effective leadership is intensely interpersonal rather than being "strong" and decisive, involving working with individuals and teams to "transform" teaching and learning. Leaders' relationships with their "followers" have 
thus assumed greater importance than the more technical aspects of administration, management, and decision-making. Leadership is essential in creating positive, innovative learning cultures and the facilitation of quality teaching and learning. It has been recognizing that positive school culture can take years to develop, with there being powerful yet complicated to discern deeply rooted causes and manifestations of school culture. Leadership is highly influential in the development of such a culture (Dinham, 2005). However, leadership succession is also a vital issue. Hargreaves and Fink (2004) note how highly successful and dynamic schools can quickly decline with the departure of an effective leader.

The situation in the world of education, which is not yet fully oriented towards the development of student's character, and still often only in the interests of the authorities or political interests, must immediately take action to save education. The principal has an essential role in realizing the character education of the child-friendly school. Education must be returned to the initial goal of the students being the center of learning, and not just understanding knowledge but morals, morals, attitudes, better known as character education. The urgency of the character education program must be implemented immediately to save the young generation of Indonesia, and the school principal as a leader in the education unit is at the forefront to make it happen.

There are many ways that school principals influence school members to work. Based on various perspectives, different approaches may be developed to lead, manage or control. For example, using the classical management theory, a principal may initiate formal structures such as roles, policies, rules and regulations, rewards, and punishments to manage school members' behavior. This leadership approach is usually known as structural or technical leadership. Alternatively, in the human relations tradition, a principal has to satisfy school members' social needs to motivate them to work: this is labeled as social leadership. (Cheong, 2000). Thus, this study aims to find out more about how the principal's leadership realizes character education.

\section{METHODS}

This research can be categorized as a literature review research. The purpose of conducting a literature review is to obtain a theoretical foundation that can support the solution of the problem being studied. The review process begins with a search engine, google scholar, to search for articles with keywords-principal in realizing character education. The search ranged from 2015-2019 and identified a total of 200 studies and articles. The criteria for inclusion in this study are as follows:

Qualitative results from principals' leadership in realizing character education

1. Research carried out in the world

2. This research uses English

3. Dissertations and theses are excluded.

Tabel 1. Principal's Leadership In Realizing Character Education

\begin{tabular}{|c|c|c|c|c|c|}
\hline $\begin{array}{l}\text { Writer and } \\
\text { Year }\end{array}$ & Title & Country & Method & Sample & Result \\
\hline $\begin{array}{l}\text { Brooks, } \\
\text { Jefrey S, } \\
\text { Hughes, } \\
\text { Roxanne M, } \\
\text { Melanie C, } \\
2008\end{array}$ & $\begin{array}{l}\text { Fear and } \\
\text { Trembling in } \\
\text { the } \\
\text { American } \\
\text { High School: } \\
\text { Educational } \\
\text { Reform and } \\
\text { Teacher } \\
\text { Alienation }\end{array}$ & USA & Qualitative & $\begin{array}{l}42 \\
\text { Teache } \\
\text { rs }\end{array}$ & $\begin{array}{l}\text { One of the } \\
\text { contributions of this } \\
\text { study is that it } \\
\text { suggests that the } \\
\text { sociological cost, in } \\
\text { terms of alienation, } \\
\text { extends beyond } \\
\text { work-life and } \\
\text { influence teachers' } \\
\text { lives en toto }\end{array}$ \\
\hline
\end{tabular}




\begin{tabular}{|c|c|c|c|c|c|}
\hline $\begin{array}{l}\text { Writer and } \\
\text { Year }\end{array}$ & Title & Country & Method & Sample & Result \\
\hline $\begin{array}{l}\text { Eissa Al- } \\
\text { Safran, } \\
\text { David } \\
\text { Brown, } \\
\text { Alexander } \\
\text { Wiseman }\end{array}$ & $\begin{array}{l}\text { The effect } \\
\text { of } \\
\text { principal's } \\
\text { leadership } \\
\text { style on } \\
\text { school } \\
\text { environme } \\
\text { nt and } \\
\text { outcome }\end{array}$ & $\begin{array}{l}\text { Kuwait, } \\
\text { USA }\end{array}$ & $\begin{array}{l}\text { Quantitativ } \\
\text { e }\end{array}$ & $\begin{array}{l}56 \\
\text { schools } \\
\text { USA, } 27 \\
\text { schools } \\
\text { Kuwait }\end{array}$ & $\begin{array}{l}\text { There exists a } \\
\text { cause/effect, direct } \\
\text { and indirect } \\
\text { relationship } \\
\text { between a } \\
\text { principal's leadership } \\
\text { style and school } \\
\text { outcome. An } \\
\text { indirect one is where } \\
\text { the principal's } \\
\text { leadership style } \\
\text { influences the } \\
\text { school's } \\
\text { environment, } \\
\text { impacting the } \\
\text { school's outcome. }\end{array}$ \\
\hline $\begin{array}{l}\text { Felipe } \\
\text { Aravena } \\
\text { (2017) }\end{array}$ & $\begin{array}{l}\text { Destructive } \\
\text { Leadership } \\
\text { Behavior: } \\
\text { An } \\
\text { Exploration } \\
\text { Study in } \\
\text { Chile }\end{array}$ & Chile & $\begin{array}{l}\text { Qualitative } \\
\text { research } \\
\text { based on } \\
\text { the } \\
\text { phenomen } \\
\text { on of } \\
\text { interpretatio } \\
n\end{array}$ & $\begin{array}{l}207 \\
\text { (34\%) } \\
\text { One of } \\
\text { the } \\
\text { contrib } \\
\text { utions } \\
\text { of this } \\
\text { study is } \\
\text { that it } \\
\text { suggest } \\
\text { s that } \\
\text { the } \\
\text { sociolo } \\
\text { gical } \\
\text { cost, in } \\
\text { terms } \\
\text { of } \\
\text { alienati } \\
\text { on, } \\
\text { extends } \\
\text { beyond } \\
\text { work- } \\
\text { life and } \\
\text { influen } \\
\text { ce } \\
\text { teache } \\
\text { rs' lives } \\
\text { in toto }\end{array}$ & $\begin{array}{l}\text { Leaders often } \\
\text { labeled as } \\
\text { destructive show } \\
\text { autocratic } \\
\text { leadership, poor } \\
\text { communication, } \\
\text { inconsistent/erratic } \\
\text { behavior, and poor } \\
\text { strategic skills. }\end{array}$ \\
\hline $\begin{array}{l}\text { Melanie C. } \\
\text { Brooks \& } \\
\text { Jeffrey S. } \\
\text { Brooks } \\
(2018)\end{array}$ & $\begin{array}{l}\text { Culturally } \\
\text { (ir)relevant } \\
\text { school } \\
\text { leadership: } \\
\text { Ethnoreligio } \\
\text { us conflict } \\
\text { and school } \\
\text { administrati }\end{array}$ & Philippines & Qualitative & $\begin{array}{l}42 \\
\text { Princip } \\
\text { als }\end{array}$ & $\begin{array}{l}\text { The principal in } \\
\text { Northern Mindanao } \\
\text { is a leader that is } \\
\text { not culturally } \\
\text { relevant. They } \\
\text { perpetuate the } \\
\text { status quo of } \\
\text { marginalization of } \\
\text { students from } \\
\text { various }\end{array}$ \\
\hline
\end{tabular}




\begin{tabular}{|c|c|c|c|c|c|}
\hline $\begin{array}{l}\text { Writer and } \\
\text { Year }\end{array}$ & Title & Country & Method & Sample & Result \\
\hline & $\begin{array}{l}\text { on in the } \\
\text { Philippines. }\end{array}$ & & & & $\begin{array}{l}\text { backgrounds. As a } \\
\text { result, some } \\
\text { students receive } \\
\text { the opportunity to } \\
\text { get a quality } \\
\text { education while } \\
\text { others do not. }\end{array}$ \\
\hline $\begin{array}{l}\text { Lijuan Li } \\
\text { Philip } \\
\text { Hallinger } \\
\text { James Ko, } \\
2016\end{array}$ & $\begin{array}{l}\text { Principal } \\
\text { leadership } \\
\text { and school } \\
\text { capacity } \\
\text { effects on } \\
\text { teacher } \\
\text { learning in } \\
\text { Hong Kong }\end{array}$ & Honk Kong & Qualitative & $\begin{array}{l}32 \\
\text { Schools }\end{array}$ & $\begin{array}{l}\text { The study sought to } \\
\text { explore how } \\
\text { dimensions of } \\
\text { leadership and } \\
\text { school capacity } \\
\text { were } \\
\text { related to reported } \\
\text { levels of teacher } \\
\text { professional learning } \\
\text { in our sample of } 32 \\
\text { Hong } \\
\text { Kong primary } \\
\text { schools. In general, } \\
\text { the capacity } \\
\text { dimensions } \\
\text { evidenced higher } \\
\text { mean } \\
\text { scores and more } \\
\text { minor standard } \\
\text { deviations than } \\
\text { those for principal } \\
\text { leadership }\end{array}$ \\
\hline $\begin{array}{l}\text { Stephen } \\
\text { Dinham, } \\
2005\end{array}$ & $\begin{array}{l}\text { Principal } \\
\text { leadership } \\
\text { for } \\
\text { outstandin } \\
g \\
\text { education } \\
\text { al } \\
\text { outcomes }\end{array}$ & Australia & Qualitative & $\begin{array}{l}38 \\
\text { Schools }\end{array}$ & $\begin{array}{l}\text { Given the project, } \\
\text { the aim was to } \\
\text { identify and } \\
\text { investigate faculties } \\
\text { and teams } \\
\text { producing } \\
\text { outstanding } \\
\text { educational } \\
\text { outcomes in Years } 7 \\
\text { to 10, rather than } \\
\text { effective schools as } \\
\text { a whole or effective } \\
\text { Principals. }\end{array}$ \\
\hline $\begin{array}{l}\text { Cheng Yin } \\
\text { Cheong }\end{array}$ & $\begin{array}{l}\text { The } \\
\text { Characteris } \\
\text { tics of } \\
\text { Hong Kong } \\
\text { School } \\
\text { Principals' } \\
\text { Leadership: } \\
\text { The } \\
\text { Influence } \\
\text { of Societal } \\
\text { Culture }\end{array}$ & Hongkong & Quantitatif & $\begin{array}{l}60 \\
\text { Schools }\end{array}$ & $\begin{array}{l}\text { As school leaders } \\
\text { must deal with } \\
\text { these challenges, } \\
\text { principal leadership } \\
\text { becomes crucial } \\
\text { for leading change } \\
\text { and enhancing } \\
\text { school } \\
\text { effectiveness and } \\
\text { educational } \\
\text { performance. }\end{array}$ \\
\hline
\end{tabular}




\begin{tabular}{|c|c|c|c|c|c|}
\hline $\begin{array}{l}\text { Writer and } \\
\text { Year }\end{array}$ & Title & Country & Method & Sample & Result \\
\hline $\begin{array}{l}\text { Battistich, } \\
\text { Victor, } 2005\end{array}$ & $\begin{array}{l}\text { Character } \\
\text { education, } \\
\text { prevention, } \\
\text { and } \\
\text { positive } \\
\text { youth } \\
\text { developme } \\
\text { nt }\end{array}$ & USA & Qualitative & & $\begin{array}{l}\text { The primary } \\
\text { argument } \\
\text { advanced here is } \\
\text { that by having } \\
\text { schools focus on } \\
\text { comprehensive } \\
\text { character } \\
\text { education-i.e., } \\
\text { promoting the } \\
\text { positive } \\
\text { development of } \\
\text { young people, not } \\
\text { just academically } \\
\text { but also emotionally, } \\
\text { ethically, and } \\
\text { socially-they may } \\
\text { not only promote } \\
\text { students' overall } \\
\text { positive } \\
\text { development as } \\
\text { individuals and } \\
\text { citizens but also } \\
\text { effectively prevent } \\
\text { the occurrence of a } \\
\text { wide range of } \\
\text { current social } \\
\text { problems among } \\
\text { our youth. }\end{array}$ \\
\hline $\begin{array}{l}\text { Smith, } \\
\text { Wilma F.; } \\
\text { Andrews, } \\
\text { Richard L., } \\
1989\end{array}$ & $\begin{array}{l}\text { Instructiona } \\
\text { I } \\
\text { Leadership: } \\
\text { How } \\
\text { Principals } \\
\text { Make a } \\
\text { Difference }\end{array}$ & USA & Qualitative & & $\begin{array}{l}\text { The clinical } \\
\text { supervision model } \\
\text { can be a dynamic } \\
\text { force in helping } \\
\text { principals improve } \\
\text { their supervision and } \\
\text { evaluation skills, as } \\
\text { we have seen in the } \\
\text { examples of } \\
\text { principals at all } \\
\text { levels working } \\
\text { collaboratively with } \\
\text { their } \\
\text { superintendents. }\end{array}$ \\
\hline
\end{tabular}

\section{RESULTS AND DISCUSSION}

This section reports the main findings reviewed from several articles the author has read. Analysis shows that most articles focus on how the principal's leadership is and how character education is. The articles that have been reviewed are research conducted in a world context. Table 1 explains the results of the literature review conducted by the authors. The results of the majority of studies indicate that it is difficult to obtain literature that combines the two variables so that the writer will positively explain the findings for each variable. The results of research on the principal's leadership show that the principal in carrying out his role as a leader impacts 
the realization of the character of learners. The results on the principal's leadership to realize character education experience, students' educational benefits, and social development while studying. The broad conclusion is that when the authors consider all the review studies on the leadership of principals in realizing character education conducted in various countries in the world, it shows that the leadership style and leadership of principals are very important for organizations including educational institutions and have positive and negative impacts due to their influence towards academics in education.

The premise of this article is to find out how the principal's leadership in realizing character education. Given the novelty of research on principals 'leadership in realizing chessentilation, there has been $n$ no research exploring this relationship. The findings of this study are noteworthy; the importance of understanding principals' leadership in realizing character education requires further discussion. The main finding of this article is that it is difficult to obtain literature that combines the two variables so that the writer will positively explain the findings for each variable. The findings are related to character education that there are still many who see that character is related to good habits and bad habits. (Lapsley \& Narvaez, 2007). Findings related to principals' leadership indicate that principals consider training activities related to human resources, executive leadership, school culture, and strategic operations to have a "high" influence on their effectiveness as school leaders. This review has limitations including; First, it is only reviewed in English, so other studies are not reviewed due to limitations. Second, this article does not discuss dissertations and theses because they can cause publication bias in the results. Third, the scope of the article reviewed is firmly minimal, and it is not easy to get literature that combines the two variables.

\section{CONCLUSION}

Principal leadership is essential for the success of school organizations because leaders create positive changes in education by encouraging staff in the school to take the initiative and change. In implementing the education program code, principals need to have a style of leadership that is appropriate to carry out the program are optimal. The principal's leadership can influence educators through teaching and non-instructional assignments, the level and manner of the principal's leadership influencing student learning outcomes depending on the particular behavior and overall features of the school environment, namely: principals, teachers, students, and community contexts. The results of most studies indicate that it is difficult to obtain literature that combines the two variables. Therefore, it is necessary to follow up on the principal's leadership research in realizing character education.

\section{ACKNOWLEDGEMENTS}

In conducting this research, many people offered their invaluable support in various ways to provide motivation and guidance. We want to thank Mr. Hasan Hariri, who has been 
patient and always gives endless support and participation in this research. We would also Thank Mrs. Sowiyah as an academic advisor who is willing to take the time and provide support amid a busy schedule and still participate in this research.

\section{REFERENCES}

Al-Safran, E., Brown, D., \& Wiseman, A. (2014). The Effect of Principal's Leadership Style on School Environment and Outcome. Research in Higher Education Journal, 22.

Aravena, F. (2019). Destructive leadership behavior: An exploratory study in Chile. Leadership and Policy in Schools, 18(1), 83-96. doi:10.1080/15700763.2017.1384501

Battistich, V. (2005). Character education, prevention, and positive youth development. Washington, DC: Character Education Partnership.

Berkowitz, M. W. (2002). The science of character education. Bringing in a new era in character education, 508, 43-63.

Brooks, J. S., Hughes, R. M., \& Brooks, M. C. (2008). Fear and trembling in the American high school: Educational reform and teacher alienation. Educational Policy, 22(1), 45-62. doi:10.1016/S0169-7722(03)00158-X

Cheong, C. Y. (2000). The characteristics of Hong Kong school principals' leadership: The influence of societal culture. Asia Pacific Journal of Education, 20(2), 68-86. doi:10.1080/02188791.2000.10600184

Da'as, R. a. (2017). School principals' leadership skills: measurement equivalence across cultures. Compare A Journal of Comparative and International Education, 47(2), 207222. doi:10.1080/03057925.2016.1210504

Dinham, S. (2005). Principal leadership for outstanding educational outcomes. Journal of educational administration, 43(4), 338-356. Retrieved from https://doi.org/10.1 108/09578230510605405. doi:10.1 108/09578230510605405

Eyal, O., \& Roth, G. (2011). Principals' leadership and teachers' motivation. Journal of educational administration. doi:10.1108/09578231111129055

Kang, S. (2008). Character education. Yangseowon Pub.

Lapsley, D. K., \& Narvaez, D. (2007). Character education. Handbook of child psychology, 4. doi:10.1002/9780470147658.chpsy0407

Li, L., Hallinger, P., \& Ko, J. (2016). Principal leadership and school capacity effects on teacher learning in Hong Kong. International Journal of Educational Management. doi:10.1108/IJEM-03-2014-0035

Lickona, T. (1996). Eleven principles of effective character education. Journal of moral Education, 25(1), 93-100. doi:10.1080/08878730701838983 
Milson, A. J., \& Mehlig, L. M. (2002). Elementary school teachers' sense of efficacy for character education. The Journal of Educational Research, 96(1), 47-53. doi:10.1080/00220670209598790

Nir, A. E., \& Kranot, N. (2006). School Principal's Leadership Style and Teachers' Self-Efficacy. Planning and Changing, 37, 205-218.

Otten, E. H. (2000). Character Education. ERIC Digest.

Pala, A. (2011). The need for character education. International Journal of Social Sciences and Humanity Studies, 3(2), 23-32.

Pihie, Z. A. L., Bagheri, A., \& Asimiran, S. (2014). School leadership and innovative principals: implications for enhancing principals' leadership knowledge and practice. Paper presented at the European Conference on Management, Leadership \& Governance.

Smith, W. F., \& Andrews, R. L. (1989). Instructional leadership: How principals make a difference: ERIC.

Wibowo, I. T., Madjid, A., \& Marietta, J. R. (2018). Pendidikan Perdamaian Sebagai Strategi Dalam Pencegahan Konflik di SMA Kolese De Britto. Damai dan Resolusi Konflik, 4(2). 